\title{
LONG SHOT: \\ The prospects for a Conversion to Euro Pricing in Oil Markets
}

MARK E, IRVINE

OIL IS CURRENTLY BOUGHT AND SOLD IN U.S. DOLLARS ON THE MAJOR OIL MARKETS. RECENT RHETORIC INDICATES SOME EXPORTERS ARE CONSIDERING SUPPORTING A CONVERSION TO EURO PRICING OF OIL. YET, THE DOLLAR HAS A FIRM GRIP. A SWITCH IS UNLIKELY IN THE SHORT- TO MEDIUM-TERM AS IT WOULD BE EXCEEDINGLY DIFFICULT GIVEN THE STRUCTURE AND INERTIA INHERENT IN OIL MARKETS ALONG WITH THE EURO'S SECOND TIER STATUS TO THE DOLLAR. THE TURBULENT POLITICS OF MANY OIL EXPORTING COUNTRIES-ESPECIALLY ISLAMIC ONES-COULD SPUR A SPITEFUL MOVEMENT TO END DOLLAR PRICING BUT THE SIGNIFICANT OBSTACLES PRODUCERS MUST OVERCOME MAY BE TOO GREAT FOR NOW. HOWEVER, BOTH ECONOMIC AND NON-ECONOMIC POLITICAL CONCERNS AS A SOURCE OF CHANGE BECOME MORE PROBABLE AS THE TIME HORIZON IS EXTENDED, ALLOWING TIME FOR THE EURO TO MATURE AND ACHIEVE A GREATER STAKE IN INTERNATIONAL FINANCIAL MARKETS. 


\section{"If the dollar is going to be dethroned. . . it will be as a result of the burgeoning resentment felts towards the United States across the world."}

In October 2003, on his visit to Moscow, German Chancellor Gerhard Schroeder responded with barely-tempered exuberance to Russian President Vladimir Putin's suggestion of pricing Russian oil in euros. Back in the Euro-zone, Italian Prime Minister Silvio Berlusconi quickly signaled his enthusiastic approval. ${ }^{i}$ Although the proposal was nothing more than the latest Russian trial balloon, the comments turned a few heads. However, this discussion did not begin with Putin's comments. In fact, the now deposed dictator and accused war criminal Saddam Hussein was a onetime petro-euro poster boy-in 2000 , he declared that Iraq would only accept payment for oil in euros, jump-starting the most recent buzz. ${ }^{\text {ii }}$ Additionally, former Malaysian Prime Minister Mahathir Mohamad has been a frequent advocate of abandoning dollar pricing, iii and the Organization for Petroleum Exporting Countries (OPEC) has addressed the issue in formal statements. This issue, still largely under the radar in the United States, raises important questions. Will the switch actually happen? What would it mean for the United States? The purpose of this paper is to explore this possibility and evaluate the probability and impact of its possible outcomes. Although oil exporters are not likely to push for the pricing of oil in euros in the near-term due to significant inertia in financial markets, the possibility becomes more probable as the time horizon is extended and political considerations are factored in. The effects of a switch are difficult to predict, but it would make the U.S. economy more susceptible to exchange rate volatility, hinder U.S. borrowing, and could even provide a shock to the international monetary system strong enough to usher in an era of monetary bipolarity or even euro dominance.

\section{OIL MARKETS AND THE DOLLAR}

Oil exporters are unlikely to mobilize to change the currency denomination of oil to euros in the short-term, be- cause of the structure and inertia inherent in oil markets and the euro's continued second tier status to the dollar. First, oil markets are highly institutionalized. The current oil pricing scheme began in 1987 after the "fixed (or administered) price system collapsed in 1985." iv It is a mindnumbing, highly complex, "market related price formulae system" built around the dollar.v Since oil varies widely in quality, markets trade contracts for certain "marker crudes" (Brent North Sea, West Texas Intermediate (WTI), and Dubai), which establish reference prices. ${ }^{\text {vi }}$ Other grades of oil have prices that are calculated from these markers. vii The principal markets they are traded on are London's International Petroleum Exchange (IPE) and the New York Mercantile Exchange (NYMEX). viii A currency change would cause major disruption; for instance, the futures trading and hedging that occur based on the dollar would see significant effects. When such a complex market structure develops around a single currency, it is difficult to change it.

Second, the dollar has several advantages as an incumbent currency in international finance generally, and in oil markets specifically. The dollar is a very well-entrenched incumbent. Texas was the original Saudi Arabia, and the United States has been the dominant global economic power since the Second World War. The dollar has a "share of currency markets about four times as great as its share of world output and trade." ix Not only does the United States import the most oil, writes Ramzi Salman, but "most other oil importers and the OPEC countries themselves are dollar-related if not linked. It is by far the main currency of pricing for most of the internationallytraded commodities, goods, and services. The dollar is also the currency of choice of most personal savings and trade in many countries such as Russia, FSU, Eastern Europe and others." ${ }^{x}$ Will this new phenomenon-the 
emergence of the euro as a challenger currency-make a difference? ${ }^{\text {xi }}$

The most recent case of a rising challenger currency was the dollar in ascendancy against the weakening British sterling in the first half of the 2oth century. The dollar won. However, that does not tell the whole story. The case demonstrates the advantages of incumbency. "Sterling preserved a global role far in excess of the strength of the British economy for half a century. The dollar will probably remain the top currency for the indefinite future," writes Fred Bernstein of the Institute for International

\section{THE EURO}

The lack of understanding regarding oil exporters' role in any possible change in currency denominations has led many to ignore the massive structural hurdles that would have to be overcome if a switch were to take effect. For instance, OPEC cannot simply announce that it will begin pricing oil in euros (as many reports suggest), because OPEC does not set oil prices, the markets do. In a speech two years ago in Spain Javad Yarjani, the head of OPEC's Petroleum Market Analysis Department, said that "there is not much [OPEC] can do unilaterally until, and unless, there is a switch of denomination on these markets." ${ }^{x i v}$ Yet,

\section{"It would take a coordinated effort of the majority of producers to effect a switch."}

Economics.xii The U.S. economy was much larger than Britain's at the time and still climbing. Since the Eurozone's economy is in no position to surpass the U.S. economy by any comparable margin, the dollar's grip looks even safer.

A change in the currency used to price oil would require collective action by the largest producers, since the system in place for pricing oil is an interconnected global market. The oil pricing system is often misunderstood. News reports sometimes confuse or gloss over the distinction between requiring payment in euros and pricing oil in euros. For instance, Saddam's Iraq did not price oil in euros; it simply accepted payment in that currency for contracts that were priced in dollars. This option is unattractive for most producers because it increases their exposure to "currency risk" - essentially shifting the volatility from the buyer to the producer. ${ }^{\text {iiii }}$ Currently, once a contract is negotiated, the producer is guaranteed a payment in dollars at the end of an agreed upon period, commonly thirty days. Thus, the buyer carries the currency risk by assuming responsibility for changing currency into dollars to pay the producer at the end of the term. producers do hold the significant "power to make major changes." xv The catch is they cannot act alone. It would take a coordinated effort of the majority of producers to effect a switch. Even OPEC does not have this weight on its own, as it amounts to about one-third of global production. If one country — even a large one-attempted to establish its own oil market, as Russian President Vladimir Putin has suggested, it would be unsuccessful. The problem is that arbitrage would occur between markets. ${ }^{x v i}$ The new market would mirror the established dollar denominated markets, but there would be much greater volatility as price shifts would follow changes in the exchange rate. This volatility would largely cancel the principal benefit of pricing in euros: price stability.

Finally, oil exporters will give the euro time to mature before making a decision on whether or not to support euro pricing. Addressing the current state of the euro, Yarjani says that OPEC is "assessing how the euro will settle into its life as a new currency." xvii Currently, more than two-thirds of the world's currency reserves are held in dollars, while about 15 percent are held in euros. The euro however has been increasing its share every year at the dollar's expense. 
The euro's advantages and disadvantages aside, the currency simply needs more time to develop.

As the euro matures as a currency it is impossible to rule anything out. The euro certainly has the potential to rise to a level where it could supplant the dollar as the primary currency in which oil prices are denominated. Even Fred Bergsten, a strong believer in the power of market inertia, believes the euro will approach parity with the dollar someday. They will ultimately each "wind up with about 40 percent of world finance."xviii When will it get to that point? Two factors that could cause the euro to catch up to the dollar very quickly are a prolonged weakness of the dollar caused by the unsustainability of the United States' borrowing position and political concerns.

With a continually weakening dollar, oil exporting countries stand to suffer significant losses as the real value of their oil revenue, which depends on the value of the dollar, continues to decline. The dollar should remain depressed for some time. The factors causing the depreciation remain in place. Interest rates remain relatively low and the twin deficits-trade and budget-have increased. The trade deficit in goods and services increased to \$6I7.I billion in 2004 from $\$ 496.5$ billion in 2003 and \$42I.7 billion in 2002. ${ }^{x i x}$ The budget deficit in fiscal year 2003 was $\$ 377.6$ billion, increased to $\$ 4 \mathrm{I} 2 . \mathrm{I}$ billion in FY 2004 , and is projected to decrease to $\$ 365$ billion in FY 2005 in a massive $\$ 2.425$ trillion budget.xx The 2005 number is widely expected to be revised upwards before the FY ends in October as additional costs, such as supplemental funding for Iraq, are added. Already OPEC is responding. In December 2004 it was reported that OPEC countries decreased their "deposits denominated in dollars by more than I3 percentage points in the past three years, mainly to the advantage of the euro."xxi

\section{THE POLITICS OF OIL}

If there is a wild card in the economics of the currency denomination of oil, politics is it. It is the only category that, by itself, has the ability to make many of the above argu- ments irrelevant. If the dollar is going to be dethroned in oil markets in the foreseeable future, it will be as a result of the burgeoning resentment felt towards the United States across the world. Some leaders within the OPEC cartel are attempting to orchestrate what has been referred to as a "monetary jihad"xxii to unseat the dollar as the king of world oil markets. Although it would not seem to make economic sense to do so, the fundamental problem is states do not behave as perfectly rational units. Leaders can make decisions that are not only irrational from an economic point of view, but that even oppose their state's collective interests. These leaders often have personal interest in mind. The 1973 oil embargo of the United States and the Netherlands is just one example of OPEC placing politics first.

Drawing on the scapegoat theory, which proposes that political leaders with domestic problems sometimes choose "to embark on aggressive foreign policies" to divert public attention from their own failings, xxiii one can imagine situations where leaders would get behind the movement to switch the pricing of oil to euros simply to punish the United States. Such a tactic is used as a diversion from a government's domestic problems, capitalizing on the "us versus them" mentality that predominates when an outside party is demonized. Pushing a trans-ition to the euro would be a relatively low cost application of this tactic. OPEC has eleven members with diverse interests. If leaders in OPEC countries believe there are compelling political gains to be had by embracing a "monetary jihad" and advocating a switch to pricing oil in euros, they are likely to discount the economic rationale for dollar pricing. Additionally, the major oil exporting countries in the Middle East are predominantly Muslim and characterized by unelected governments. These types of governments-those lacking strong sources of legitimacy-are the most likely to turn to this kind of tactic in the first place and, considering their deep resentment towards the United States already, there is a chance it could work despite the quite significant structural obstacles. xxiv 


\section{EFFECTS OF CHANGING}

If the euro does somehow (partially or fully) supplant the dollar as the principal currency oil is priced in, the following could be expected. First, the United States would experience greater price volatility as exchange rates would have to be factored into oil prices. If oil was priced in euros, the United States would have to first buy euros and then use those to buy oil. Thus, an appreciation or depreciation of the dollar would have a direct effect on oil prices-a phenomena the rest of the world has always dealt with, but which would be new to the United States. Yet although this arrangement is not the optimal one, there is reason to believe the United States would be able to adapt without serious economic losses. As Robert Solomon says, exchange rates would affect the price of oil, but it would not be "a major, major problem."xxv

Second, the U.S. borrowing position could become untenable. The rise of the euro would "reduce the ability of the United States to finance its large external deficits," writes Bergsten. xxvi The current account deficit would quickly become unsustainable as countries decreased their dollar reserves (and hence, demand for U.S. treasury bills). The severity of the crisis would vary; but at the very least, the United States would have to pursue more restrictive monetary and fiscal policies.

Third, an unexpected or sudden switch to the euro could act as the "shock large enough to shift [the exchange rate structure] from one equilibrium to another."xxvii The dollar was thrust past the sterling after its devaluation in I931, never looking back.xxviii The magnitude of this impact would clearly depend on how established the euro is as an exchange and reserve currency at the time of the switch and whether the switch is partial or absolute. For example, oil could be priced in a basket of currencies, which would affect everyone roughly equally. The impact might not be too severe. If the change is gradual and expected, then the psychological effects and supposed ensuing massive sell-off of dollars and dollar assets is likely to be minimized.
Although the possibilities are interesting to examine, in reality we are unlikely to see a situation where the euro supplants the dollar in the near future, rumors aside. It is clear that the euro has the potential to ruffle feathers further down the line, but it is not there yet. Since oil markets are sufficiently routinized, supplanting the dollar-centered system with a system centered on the euro is a very difficult and costly proposition. In terms of fundamentals, the euro would have to be substantially more attractive than the dollar for it to replace the dollar on the oil markets. It becomes clear, upon examining the dollar's position, that it is still fairly secure. The continued weakness of the dollar could be a problem down the road, but extrapolating current trends into the distant future is problematic. Just five years ago it was the euro that was plunging. For now, it seems the "threat" of the petro-euro is nothing more than hype and idle chatter - a pipedream best left to the imaginations of "Old Europe" and aspiring "monetary jihadists."

\section{ENDNOTES}

i Panicker (2003)

ii Interestingly, independent news organizations, internet message boards, and even some foreign newspapers as reputable as the Guardian and the Hindu have printed pieces arguing that Saddam's announcement was the real reason for the U.S. invasion of Iraq. See Chapman (2004) and Rajaram (2003)

iii Panicker (2003)

iv Mabro (2000)

v Mabro (2000)

vi Horsnell (2000)

vii Other grades are assigned prices "using complex formulas derived from marker crudes." See Yarjani (2002).

viii Horsnell (2000)

ix Bergsten (2002), pp. 3-4

x Salman (2004)

xi Bergsten (2002) 2-3

xii Bergsten (1997)

xiii Yarjani (2002)

xiv Yarjani (2002)

xv Horsnell (2000)

xvi Mabro (2000)

xvii Yarjani (2002)

xviii Bergsten (I997)

xix BEA (2005) and BEA (2004)

$\mathrm{xx} \mathrm{CBO}$ (2005)

xxi New York Times (2004)

xxii Bush (2004), pp. 34-5

xxiii Levy (1988), p. 666 
xxiv Javad Yarjani, the head of OPEC's research arm, is quoted extensively in this paper, but his analysis should be qualified by noting that he does not account for the substantial political dimension of the issue. Speaking as the head of OPEC's Petroleum Market Analysis Department, he is approaching the question from a rational economic perspective which may not be wholly consistent with the perspective of OPEC's more political leaders. The scapegoat theory explains an exception to the assumption of state-level rationality. See Yarjani (2002)

\section{REFERENCES}

Bergsten, C. Fred. 2002. "The Euro Versus the Dollar: Will There Be a Struggle For Dominance?” Presented to a Roundtable at the Annual Meeting of the American Economic Foundation, Atlanta, January 4, pp. 3-4.

Bergsten, C. Fred. I997. "The Dollar and the Euro." Foreign Affairs, 76 (4), July/August.

Bureau of Economic Analysis. 2005. "Trade Gap Widens in 2004." March II.

Bureau of Economic Analysis. 2004. "U.S. International Trade in Goods and Services (Seasonally Adjusted)." June I4.

Bush, Janet. 2004. "America's Foes Prepare for a Monetary Jihad." New Statesman, October 4, pp. 34-5.

Chapman, John. 2004. "The Real Reasons Bush Went to War." The Guardian, July 28.

Congressional Budget Office. 2005. "The Budget and Economic Outlook: Fiscal Years 2006-2015." January.

Horsnell, Paul. 2000. "Oil Pricing Systems." Oxford Energy Comment, Oxford Institute for Energy Studies, May.

Levy, Jack S. 1988. "Domestic Politics and War." Journal of Interdisciplinary History, 28 (4), p. 666

Mabro, Robert. 2000. "Oil Markets and Prices." Oxford Energy Comment, Oxford Institute for Energy Studies, August.

Panicker, G. 2003. "Will Oil Trading Soon Be Conducted in Euros?" Business Times Singapore, October 28.

Portes, Richard and Hélène Rey. 1998. "The Emergence of the Euro as an International Currency," NBER Working Paper 6424 , February 9.

Rajaram, N.S. 2003. "The Shadow War: Euro vs. Dollar." The Hindu, April 22.
Reuters. 2004. "OPEC Nations Seen Cutting Worldwide Deposits in Dollars." New York Times, December 6.

Salman, Ramzi. 2004. "The US Dollar and Oil Pricing Revisited." Middle Eastern Economic Review, 47 (I), January 5 .

Solomon, Robert. 1999. "The Birth of the Euro: How Will it Affect the World Economy?" Speaking event at the Brookings Institution, January 7 .

Yarjani, Javad. 2002. "The Choice of Currency for the Denomination of the Oil Bill." Speech given in Oviedo, Spain on April I4. 